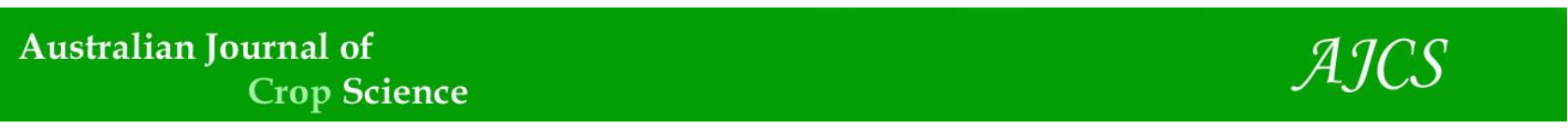

AJCS 15(10):1263-1268 (2021)

ISSN:1835-2707

doi: 10.21475/ajcs.21.15.10.p3159

\title{
Application of glycine on soybean plants submitted to water deficit
}

\author{
Walquíria Fernanda Teixeira' ${ }^{1}$, Luís Henrique Soares ${ }^{2}$, Klaus Reichardt ${ }^{3,4}$, Durval Dourado Neto ${ }^{3}$ \\ ${ }^{1}$ Agronomist, PhD in Plant Science. Orcid id: 0000-0002-0641-0815 \\ ${ }^{2}$ University Center of Patos de Minas - Unipam, 38700-207, Patos de Minas, Minas Gerais, Brazil \\ ${ }^{3}$ Crop Science Department, "Luiz de Queiroz" College of Agriculture - Esalq/USP, 13418-970, Piracicaba, São Paulo, \\ Brazil. \\ ${ }^{4}$ Center for Nuclear Energy in Agriculture, University of Sao Paulo, Av. Centenário, 303, 13400-970, Piracicaba, São \\ Paulo, Brazil
}

\begin{abstract}
Soybean is one of the most important crops in the world. Studies are necessary to improve its productivity, especially in stress environments. Therefore, the objective of this study was to evaluate the effect of glycine as seed treatment to soybean plants submitted to water deficiency, using twelve replicates per treatment. Glycine was applied at a dose of $9 \mathrm{mg} \mathrm{kg}^{-1}$ of seeds under high water deficit (performed at stage V4) and without water deficiency. Root development, antioxidant metabolism and dry mass accumulation of plants were evaluated. Results showed that the application of glycine to plants that were not subjected to water deficiency, promoted the increase of root development, accumulation of mass and reduction of stress in plants. This reflected in $10 \%$ increase in productivity compared to the control treatment. On the other hand, plants with glycine application subjected to water deficiency showed a reduction in dry mass accumulation and root development, indicating that these plants suffered the effect of stress. Untreated plants submitted to water deficiency showed symptoms of stress such as reduced accumulation of mass and productivity by $12 \%$. Therefore, the present study reports that the application of glycine on seeds is not very efficient for attenuating stress in soybean plants submitted to water deficiency. However, in environments without water deficiency, the application of glycine on seeds affects the greater development of the plant and increased productivity.
\end{abstract}

Keywords: Glycine max (L.) Merrill, seed treatment, amino acids, drought.

Introduction

Soybean is among the most economically important crops in the world, both as a commodity that participates in the future market and for its transformation into food and fiber. After a great evolution of cultivated area and increased productivity since the 90s (Cattelan and Dall'Agnol, 2017), Brazil consolidated itself as the country with the highest world production (134 million tons) and cultivated area (38.6 million hectares) in the world in the $20 / 21$ harvest (USDA, 2021). One important aspect that still to be considered is to improve soybean productivity in stress environments. Drought stands out for affecting the productivity of many regions where irrigation is not practiced or not feasible. In Brazil, research shows that the soybean yield gap due to drought can reach up to 1600 kg.ha-1 (Sentelhas et al., 2015; Reis et al., 2020). In China, soybean productivity was lost up to $21.8 \%$ at severe drought (Wang et al., 2020).

Research shows that the application of glycine seems to be a promising practice to stimulate growth or mitigate plant stresses (Mosa et al., 2021, Shooshtari et al., 2020; Mohammadipour and Souri, et al., 2019, Noroozlo et al., 2019a, Noroozlo et al., 2019b), although some reports have shown a reduction in development of plants (Matysiak et al., 2020; Khan et al., 2019). Glycine, one of the 20 essential amino acids for plants, is a neutral, non-polar amino acid, synthesized from serine during photorespiration. Part of the glycine can be converted into glutamate, which can then be metabolized to $\gamma$-aminobutyric acid (GABA) (Igamberdiev and Kleczkowski, 2018). It is already known that GABA acts as an important signal for the regulation of plant growth and development, mediating response to stress tolerance due to low light, salinity, nitrogen deficiency, water deficit, high temperatures and regulates antioxidant defense systems (Ramos-Ruiz et al., 2019). It is known that glutamate, via glutamate receptors (GLRs), is a fundamental signal for tolerance to biotic and abiotic stresses (Qiu et al., 2020).

Although not yet consolidated, there are two other plant mechanisms that may be associated with the effect of glycine on stress tolerance. First, the well-known effect of glycine betaine (GB) against plant stresses (Annunziata et al., 2019; Shehzadi et al., 2019; Xu et al., 2018). GB is synthesized from choline, which originates from the same metabolism that produces glycine (Xu et al., 2018). Some studies show that choline is synthesized from methionine (Buchanan et al., 2015), while others show that ethanolamine, the basis for choline synthesis, is synthesized from serine (Lin et al., 2020). Therefore, it is possible that there is some interaction between the glycine metabolism and glycine betaine synthesis in plants. Second, it has recently been shown that proteins rich in glycine (GRP) are involved in stress-related metabolisms. GRP are characterized by a high concentration of glycine (more than 70\%). The expression of these proteins is involved in tolerance to stresses at low and high 
temperatures, salinity, wounds, drought, oxidative stress and biotic stresses (Czolpinska and Rurek, 2018).

Thus, the glycine pool in plants may be involved in several mechanisms related to the tolerance of biotic and abiotic stresses. Although information about this is scarce, the application of glycine can also be a strategy to mitigate the effects of water deficit in plants. Teixeira et al. (2019) demonstrated that the application of proline via leaf is an efficient alternative to mitigate the effect of moderate water stress in soybeans, while under high water deficit, the application of glutamate via leaf or in the treatment of seeds is more efficient to minimize the effects of stress. However, information on the effect of glycine application on soybean crops is still scarce, especially under stressful situations.

\section{Results}

\section{Sampling performed at the V3 stage}

This analysis showed that the application of glycine provided increases of $54,53,161,55$ and $110 \%$ in the variables: projection area (PA), volume (Vol), main root length (MLR), total root length (TLR) and number of secondary roots (NSR), respectively.

However, despite these positive effects observed from the application of glycine in the parameters related to the root, there was no difference in the accumulation of dry mass in relation to the control, except in the dry mass of the stem, which increased $17 \%$ in relation to the control treatment (Table 1). The application of glycine on seeds reduced activity of some enzymes, among them the nitrate reductase (NR), and the enzymes of the antioxidant metabolism superoxide dismutase (SOD), catalase (CAT) and peroxidase (POD). This reduction reached $57 \%$ for CAT and $47 \%$ for SOD. The lower activity of antioxidant enzymes increases plant lipid peroxidation (LP) by $50 \%$.

Plants submitted to seed treatment with glycine also showed a higher concentration of proline (Prol) in the leaves (Table 2).

\section{Sampling performed at the $V_{6}$ stage}

There was a reduction in the projection area (PA), total root length (TLR) and number of secondary roots (NSR), in plants that were treated with glycine and subjected to water deficiency (Table 3). The same treatment led to a reduction in dry mass of root (RDM), stem (SDM), leaves (LDM) and total (TDM). The decrease reached 27,25 and $24 \%$ for the parameters of LDM, TDM and SDM, respectively, in relation to the control treatment without water deficiency. The activity of the enzymes nitrate reductase and urease was higher in plants treated with glycine and submitted to water deficiency (Table 4). Plants without treatment and subjected to water stress showed a $27 \%$ reduction in the relative leaf water content (RWC), compared to plants without water deficiency. As a consequence, there was an increase of $48 \%$ in the lipid peroxidation (LP) of these plants. Plants submitted to seed treatment with glycine and submitted to water deficiency did not show a reduction in RWC and an increase in $L P$, at stage $V_{6}$.

\section{Sampling performed at the $V_{8}$ stage}

No statistical difference was observed in the dry mass of plants at the $V_{8}$ stage. (Table 5). The same was observed in number of pods (NP). The pod dry mass (PDM) was higher in plants treated with glycine at non-stress conditions. The same plants showed higher productivity (Prod), with an increase of $10 \%$ compared to control. Plants submitted to water deficiency, with and without glycine treatment, showed lower productivity compared to other treatments.

\section{Discussion}

The application of glycine as seed treatment promoted an increase in root development at stage $V_{3}$ (Table 1). Glycine can play the role of signaling in plants, as they could bind to GLRs (Glutamate Receptors), initially so named because glutamate is the first amino acid discovered for these receptors (Dubos et al., 2003). GLRs activate calcium signals, which in turn, signal various processes in other parts of the plant, such as alteration of carbon and nitrogen metabolism (Price et al., 2012; Forde and Roberts, 2014), characteristics that can have an impact on further development of roots, as observed in our experiment. Teixeira et al. (2019), also showed that the application of glycine in seed treatment increases the development of roots in soybean plants. Some benefits of applying glycine were also observed at stage $V_{6}$ (Table 3), with an increase in RDM, TDM, SOD and a reduction in LP. Characteristics that may have had an impact on the increase in the PDM and productivity are shown in Table 5. Teixeira et al. (2018), reported an increase in productivity of plants under application of glycine at the rate of $9 \mathrm{mg} \mathrm{kg}^{-1}$ of seed, as observed in this experiment. The activation of GLRs provided by glycine can also lead to increased antioxidant metabolism and the consequent reduction in plant stress (Weiland et al., 2015). In addition, glycine is part of the structure of several proteins, mainly those linked to the formation of the cell wall, whereas about $70 \%$ of these proteins are formed by glycine (Buchanan et al., 2015, Ringli et al., 2001). Glycine can act in the stress response since it is part of the formation route of glycine betaine, a compatible solute that acts as an osmoprotector in plants, especially under salt stress conditions (Demiral and Turkan, 2006). According to Hu et al. (2012) from the production of glycine betaine, various signaling processes begin in plants, such as increased activity of antioxidant enzymes and the consequent reduction in lipid peroxidation, which was observed in this experiment. However, plants that were subjected to seed treatment with glycine and water stress showed a reduction in root parameters and mass accumulation (Table 3 ), with reduced root development and accumulation of total dry mass in plants. Cell growth is the most sensitive process to low water availability, and cell division and expansion are directly inhibited by water stress. For this reason, reduced growth is considered the first consequence of water restriction in vegetables (Taiz et al., 2017). The effect of glycine has been possibly faded up throughout the development of the plant, under stress condition and the signaling potential of this amino acid was not effective to alleviate water stress to reduce plant development. Therefore, it is believed that direct application of glycine on leaves is more effective under stress conditions, as this type of application activates the antioxidant metabolism of plants and improves the defense system (Teixeira et al., 2017). The control treatment (no-glycine) plants, subjected to water stress showed increased NSR (Table 3), possibly with the objective of increasing the water catchment area in the soil and trying to survive under stress conditions. Under water deficit conditions, the hormones abscisic acid (ABA) and 


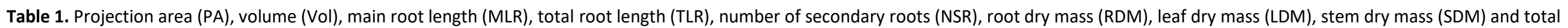
dry mass (TDM) at the $V_{3}$ stage, for soybean cultivar RK6813RR, submitted to the application of glycine (Gly) and control on seed treatment (ST).

\begin{tabular}{|c|c|c|c|c|c|c|c|c|c|}
\hline \multirow[t]{2}{*}{ Treatments } & PA & Vol & MLR & TLR & NSR & RDM & LDM & STD & TDM \\
\hline & $\mathrm{cm}^{2}$ & $\mathrm{~cm}^{3}$ & \multicolumn{2}{|l|}{$\mathrm{cm}$} & - & \multicolumn{4}{|c|}{ g plant $^{-1}$} \\
\hline Control & 56.65 & 0.17 & 92.30 & 277.0 & 34.33 & 0.129 & 0.059 & 0.052 & 0.305 \\
\hline Glycine & $87.30 *$ & $0.26^{*}$ & $241.19 *$ & $430.5^{*}$ & $72.00 *$ & 0.111 & 0.065 & $0.061 *$ & 0.299 \\
\hline
\end{tabular}

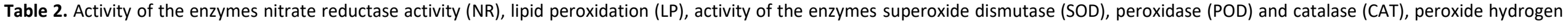
content $\left(\mathrm{H}_{2} \mathrm{O}_{2}\right)$ and proline content (Prol), at the $\mathrm{V}_{3}$ stage, for soybean cultivar RK6813RR, submitted to the application of glycine (Gly) and control on seed treatment (ST).

\begin{tabular}{|c|c|c|c|c|c|c|c|}
\hline \multirow[t]{2}{*}{ Treatments } & \multirow{2}{*}{$\mu \mathrm{g}\left[\mathrm{N}-\mathrm{NO}_{2}^{-}\right] \mathrm{g}^{-1}\left[\right.$ fresh biomas] $\mathrm{h}^{-1}$} & \multirow{2}{*}{$\begin{array}{l}\text { LP } \\
\text { nmol [TBARS] } \mathrm{g}^{-1} \text { [fresh biomas] }\end{array}$} & \multirow{2}{*}{$\begin{array}{l}\text { SOD } \\
\text { U mg [protein] }\end{array}$} & POD & CAT & $\mathrm{H}_{2} \mathrm{O}_{2}$ & Prol \\
\hline & & & & \multicolumn{2}{|c|}{$\mu \mathrm{mol} \mathrm{min}^{-1} \mathrm{mg}$ [protein] } & \multicolumn{2}{|c|}{$\begin{array}{l}\mu \mathrm{mol} \mathrm{g}{ }^{-1} \\
\text { [fresh biomas] }\end{array}$} \\
\hline Control & $4.40 *$ & 38.58 & $313.4^{*}$ & $11.98^{*}$ & $612.1^{*}$ & 4.71 & 0.04 \\
\hline Glycine & 1.57 & 57.99* & 164.2 & 1.65 & 261.1 & 4.61 & $0.10^{*}$ \\
\hline
\end{tabular}

Asterisks indicate statistically significant difference between treatments, using the Student's $t$ test, p<0.05.

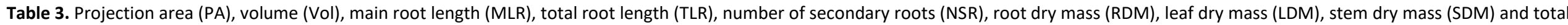

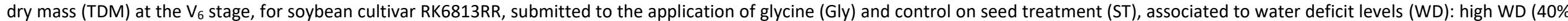
of field capacity - FC) and without WD (80\% FC).

\begin{tabular}{|c|c|c|c|c|c|c|c|c|c|c|}
\hline \multirow[t]{2}{*}{ Treatments } & \multirow{2}{*}{$\begin{array}{l}\text { Water deficit } \\
\text { level }\end{array}$} & \multirow{2}{*}{$\begin{array}{l}\mathrm{PA} \\
\mathrm{cm}^{2}\end{array}$} & \multirow{2}{*}{$\begin{array}{l}\text { Vol } \\
\mathrm{cm}^{3}\end{array}$} & \multirow{2}{*}{\multicolumn{2}{|c|}{$\begin{array}{l}\mathrm{MLR} \\
\mathrm{Cm}\end{array}$}} & \multirow{2}{*}{$\begin{array}{l}\text { NSR } \\
-\end{array}$} & \multirow{2}{*}{\multicolumn{2}{|c|}{$\begin{array}{l}\text { RDM } \\
\text { g plant }^{-1}\end{array}$}} & SDM & TDM \\
\hline & & & & & & & & & & \\
\hline \multirow[t]{2}{*}{ Control } & Without & $85.06 \mathrm{a}$ & $2.46 \mathrm{a}$ & $33.10 \mathrm{a}$ & $2306.1 \mathrm{a}$ & $2765.7 b$ & $0.60 \mathrm{~b}$ & $0.25 a b$ & $0.24 \mathrm{a}$ & $1.08 \mathrm{~b}$ \\
\hline & Hight & $87.83 \mathrm{a}$ & $2.46 \mathrm{a}$ & $33.22 \mathrm{a}$ & $2616.6 \mathrm{a}$ & 3348.3 a & $0.55 \mathrm{~b}$ & $0.29 a$ & $0.25 \mathrm{a}$ & $1.09 \mathrm{~b}$ \\
\hline \multirow[t]{2}{*}{ Glycine } & Without & $82.88 \mathrm{a}$ & $2.31 \mathrm{a}$ & 33.34 a & 2298.7 a & 2399.5 bc & $0.80 a$ & $0.29 a$ & $0.26 a$ & $1.35 \mathrm{a}$ \\
\hline & Hight & $60.30 \mathrm{~b}$ & $1.91 \mathrm{a}$ & 32.74 a & $1528.5 \mathrm{~b}$ & 2078.3 c & $0.43 c$ & $0.21 \mathrm{~b}$ & $0.19 \mathrm{~b}$ & $0.82 \mathrm{c}$ \\
\hline
\end{tabular}

Means followed by the same letters do not differ significantly from each other, using the Duncan test t $5 \%$ significance.

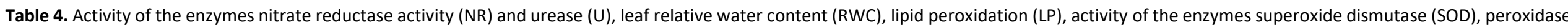

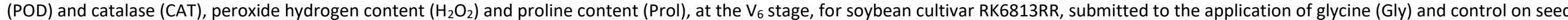
treatment (ST), associated to water deficit levels (WD): high WD (40\% of field capacity - FC) and without WD ( $80 \%$ FC).

\begin{tabular}{|c|c|c|c|c|c|c|c|c|c|c|}
\hline \multirow[t]{2}{*}{ Treatments } & \multirow{2}{*}{$\begin{array}{l}\text { Water deficit } \\
\text { level }\end{array}$} & NR & U & RWC & LP & SOD & POD & CAT & $\mathrm{H}_{2} \mathrm{O}_{2}$ & Prol \\
\hline & & $\begin{array}{l}\mu \mathrm{g}\left[\mathrm{N}-\mathrm{NO}_{2}^{-}\right] \mathrm{g}^{-1} \\
{\left[\text { fresh biomas] } \mathrm{h}^{-1}\right.}\end{array}$ & $\begin{array}{l}\mu \mathrm{mol} \quad[\mathrm{N}- \\
\left.\mathrm{NH}_{4}^{+}\right] \quad \mathrm{g}^{-1} \\
\text { [fresh } \\
\text { biomas] } \mathrm{h}^{-1}\end{array}$ & $\%$ & $\begin{array}{l}\text { nmol [TBARS] g }{ }^{-1} \\
\text { [fresh biomas] }\end{array}$ & U mg [protein] & \multicolumn{2}{|c|}{$\mu \mathrm{mol} \mathrm{min}^{-1} \mathrm{mg}$ [protein] } & \multicolumn{2}{|c|}{$\begin{array}{l}\mu \mathrm{mol} \mathrm{g}{ }^{-1} \\
\text { [fresh biomas] }\end{array}$} \\
\hline \multirow[t]{2}{*}{ Control } & Without & $23.97 b$ & $3.83 \mathrm{~b}$ & $23.30 \mathrm{a}$ & $48.44 \mathrm{~b}$ & $127.2 \mathrm{~b}$ & $1.70 \mathrm{a}$ & $80.00 \mathrm{~b}$ & $8.14 \mathrm{a}$ & $0.15 \mathrm{a}$ \\
\hline & Hight & $15.19 \mathrm{~b}$ & $4.58 \mathrm{~b}$ & $17.05 \mathrm{~b}$ & $71.55 \mathrm{a}$ & $165.1 \mathrm{ab}$ & $2.36 \mathrm{a}$ & 196.7 a & $8.35 a$ & $0.17 \mathrm{a}$ \\
\hline \multirow[t]{2}{*}{ Glycine } & Without & $16.95 b$ & $3.71 \mathrm{~b}$ & $26.25 \mathrm{a}$ & $48.90 \mathrm{~b}$ & 176.7 a & $2.44 \mathrm{a}$ & $43.29 \mathrm{~b}$ & $7.12 \mathrm{a}$ & $0.16 \mathrm{a}$ \\
\hline & Hight & $38.03 \mathrm{a}$ & $6.11 \mathrm{a}$ & $25.05 \mathrm{a}$ & $63.87 a b$ & $144.2 a b$ & $2.04 \mathrm{a}$ & $38.58 \mathrm{~b}$ & $7.21 \mathrm{a}$ & $0.25 \mathrm{a}$ \\
\hline
\end{tabular}

Means followed by the same letters do not differ significantly from each other, using the Duncan test at $5 \%$ significance. 
Table 5. Root dry mass (RDM), leaf dry mass (LDM), stem dry mass (SDM), pod dry mass (PDM), total dry mass (TDM) and number of pod (NP) at the R8 stage, and productivity (Prod), for soybean cultivar RK6813RR, submitted to the application of glycine (Gly) and control on seed treatment (ST), associated to water deficit levels (WD): high WD (40\% of field capacity - FC) and without WD (80\% $\mathrm{FC})$.

\begin{tabular}{|c|c|c|c|c|c|c|c|c|}
\hline \multirow[t]{2}{*}{ Treatments } & \multirow{2}{*}{$\begin{array}{l}\text { Water } \\
\text { deficit } \\
\text { level }\end{array}$} & RDM & LDM & STD & PDM & TDM & NP & Prod \\
\hline & & \multicolumn{5}{|l|}{ g plant $^{-1}$} & - & g plant ${ }^{-1}$ \\
\hline \multirow[t]{2}{*}{ Control } & Without & $3.39 \mathrm{a}$ & $2.09 \mathrm{a}$ & $1.79 \mathrm{a}$ & $2.31 \mathrm{ab}$ & $9.58 \mathrm{a}$ & $69.75 \mathrm{a}$ & $1.85 \mathrm{~b}$ \\
\hline & Hight & $3.97 \mathrm{a}$ & $2.36 \mathrm{a}$ & $1.80 \mathrm{a}$ & $2.41 \mathrm{ab}$ & $10.54 \mathrm{a}$ & 69.25 a & $1.62 \mathrm{c}$ \\
\hline \multirow[t]{2}{*}{ Glycine } & Without & $3.81 \mathrm{a}$ & $2.55 \mathrm{a}$ & $2.05 a$ & $2.54 \mathrm{a}$ & $10.96 \mathrm{a}$ & $70.75 \mathrm{a}$ & $2.03 a$ \\
\hline & Hight & $4.47 a$ & $2.59 a$ & $2.30 a$ & $1.92 b$ & $11.28 \mathrm{a}$ & $68.50 \mathrm{a}$ & $1.54 \mathrm{c}$ \\
\hline
\end{tabular}

Means followed by the same letters do not differ significantly from each other, using the Duncan test at $5 \%$ significance.

ethylene balance that mediates different responses in plants. $A B A$ induces stomatal closure to prevent water loss in plants. In addition, this hormone inhibits the increase of ethylene in the root, which stimulates root growth. On the other hand, the increase in ethylene in the aerial part provides a reduction in leaf growth (Salazar et al., 2015; Taiz et al., 2017). Therefore, these characteristics explain the increase in plant NSR. In addition, the stress resulted in greater lipid peroxidation and a reduction in the relative water content in the leaves, characteristics that reflected in the reduction of the productivity of these plants (Table 5 ).

\section{Materials and Methods}

\section{Experimental design and conditions}

The experiment was carried out in a greenhouse located in the University Center of Patos de Minas (Unipam), municipality of Patos de Minas, MG, Brazil ( $18^{\circ} 34^{\prime} \mathrm{S}, 46^{\circ} 31^{\prime}$ $\mathrm{W}$ and $815 \mathrm{~m}$ asl). Soybean plants [Glicyne $\max$ (L.) Merrill], cultivar RK6813RR of medium cycle and indeterminate growth habit were used in a randomized block design, consisting of the application of glycine (pure amino acid Sigma Aldrich ${ }^{\circ}$, with optical isomerism levogiro - L-amino acid) and one control (distilled water), applied as seed treatment (ST), using twelve replicates for each treatment. These treatments were associated to water deficit levels, ranging from conditions of no water deficit to high water deficit. Plants were grown in pots of $10 \mathrm{dm}^{3}$ capacity, filled with washed sand (washed sand of medium texture, with grain sizes between $0.05 \mathrm{~mm}$ and $0.8 \mathrm{~mm}$ ). During the conduction of the experiment, the pots were irrigated daily according to the water requirement. A weekly application of nutrient solution was also applied as proposed by Johnson et al. (1957). Glycine was diluted in distilled water and applied to seeds at the concentration of $9 \mathrm{mg} \mathrm{kg}^{-1}$ [seed] $(40 \mathrm{mM})$, with a volume of $4 \mathrm{~mL} \mathrm{~kg}^{-1}$ [seed]. Before sowing, seeds were treated with fungicide and insecticide (fipronil + piraclostrobin + methyl thiophanate) at the rate of $1 \mathrm{~mL} \mathrm{~kg}^{-1}$ [seeds]. The control treatment consisted of distilled water as a substitute to the diluted glycine. For the application of water deficit levels, it was necessary to determine the field capacity (FC) of the substrate (sand) in the pots. $80 \%$ of the field capacity was adopted (taken as a water potential of $-0.05 \mathrm{MPa}$ ) as the minimum soil water content for the treatment without water deficit. The treatments with high water deficit corresponded to vessels conducted at $40 \%$ of FC $(-1.5 \mathrm{MPa})$. The water deficit started when the plants were at $V_{4}$ stage (four nodes on the main stem) and maintained for a period of 15 days. The monitoring of field capacity was carried out through daily weighing of the pots and with the aid of tensiometers. The two ways of control were used together, because tensiometers do not operate for water potentials below -1 $\mathrm{MPa}$.

\section{Evaluation of characteristics}

For the biochemical determinations, samplings were performed at the $V_{3}$ (three nodes on the main stem) and $V_{6}$ (six nodes on the main stem) growth stages. Completely expanded leaves were collected from the middle third of the plants. The fresh material was used to determine the activity of nitrate reductase - NR (Mulder et al., 1959), urease - U (Hogan et al., 1983; McCullough 1967), quantification of hydrogen peroxide $-\mathrm{H}_{2} \mathrm{O}_{2}$ (Alexieva et al., 2001), lipid peroxidation - LP (Heath and Packer 1968) and proline levels (Bates et al., 1973). Quantification of antioxidant enzymes was performed with fresh leaves and frozen in liquid nitrogen shortly after collection. This material was extracted according to the protocol proposed by Kar and Mishra (1976). Then, the determination of total soluble protein content (Bradford 1976) and the enzymes catalase - CAT (CAT, Peixoto et al., 1999), peroxidase - POD (Teisseire and Guy 2000) and superoxide dismutase - SOD (Beauchamp and Fridovich 1971) were performed. The relative water content in the leaves (RWC) was analyzed at the $V_{6}$ stage, according to the method proposed by Barrs and Weatherley (1962). Root growth was evaluated at stages $V_{3}$ and $V_{6}$, using two plants per replicate. The analyses were performed using the Winrhizo ${ }^{\circledR}$ software, version 4.1, coupled to an Epson XL 10000 scanner, and followed the procedures proposed by Bouma et al. al. (2000). The program establishes a gray tonality value automatically, from which it is possible to identify each plant tissue. The main length root $(M L R, c m)$, total root length $(T L R, c m)$, projection area $\left(\mathrm{PA}, \mathrm{cm}^{2}\right)$, root volume $\left(\mathrm{cm}^{3}\right)$ and number of secondary roots (NSR) were obtained. Root (RDM), stem (SDM), leaf (LDM) and pod (PDM) dry matter mass determinations were performed at the $V_{3}, V_{6}$ and $R_{8}$ growth stages. Two plants were used per replicate, when each organ of the plant was separately packed in paper bags, and then dry mass was evaluated using an oven with forced air circulation and with a temperature of $65^{\circ} \mathrm{C}$, until constant mass. For the yield, plants were harvested manually considering three plants per replicate. The harvested grain from each plant were weighed on a digital scale with an accuracy of 0.01 grams. The water content of the grains was determined, and the productivity was calculated with the water content corrected to $13 \%\left(0.13 \mathrm{~g} \mathrm{~g}^{-1}\right)$. The result was presented in grams per plant.

\section{Statistical analysis}

Statistical analysis was performed using the Student's t-test, in the evaluations carried out at the $V_{3}$ stage, which had not yet undergone water deficit treatments. The other evaluations were compared using the Duncan Test. All tests 
performed at $5 \%$ level of significance. All analyzes were carried out with the help of statistical software SAS 9.3 (SAS Institute 2011).

\section{Conclusions}

This study showed that the application of glycine $\left(9 \mathrm{mg} \mathrm{kg}^{-1}\right)$ as seed treatment provides an increase in root growth and accumulation of dry mass in the early development of plants only at normal conditions (without water deficiency). However, these characteristics do not perpetuated when the plants were subjected to water deficiency conditions. On the other hand, in environments without water deficiency, the application of glycine in the treatment of seeds affected the greater development of the plant and increased productivity.

\section{References}

Alexieva V, Sergiev I, Mapelli S, Karanov E (2001) The effect of drought and ultraviolet radiation on growth and stress markers in pea and wheat. Plant Cell Environ 24: 1337-1344.

Annunziata MG, Ciarmiello LF, Woodrow P, Dell'Aversana E and Carillo P (2019) Spatial and temporal profile of glycine betaine accumulation in plants under abiotic stresses. Front Plant Sci. 10:230.

Barrs HD and Weatherley PE (1962) A Re-Examination of the Relative Turgidity Techniques for Estimating Water Deficits in Leaves. Aust J Biol Sci. 15, 413-428.

Bates L, Waldren RP, Teare ID (1973) Rapid determination of free proline for water-stress studies. Plant Soil 39: 205-207.

Beauchamp C, Fridovich I (1971) Superoxide dismutase: improved assays and applicable to acrylamide gels. Anal Biochem. 44(1): 276-287.

Bouma TJ, Nielson KL, Koutstaal BAS (2000) Sample preparation and scanning protocol for computerized analysis of root length and diameter. Plant Soil. 218: 185196.

Bradford MM (1976) A rapid and sensitive method for quantification of microgram quantities of protein utilizing the principle of protein-dye-binding. Anal Biochem. 72: 248254.

Buchanan BB, Gruissem, W, Jones, RL (2015) Biochemistry and molecular biology of plants. Rockville, MD: American Society of Plant Pathologists, 2nd ed.

Cattelan AJ, Dall'Agnol A (2017) The rapid soybean growth in Brazil. Oil Seed and Fat Crops Lipids. 25(1): D102.

Czolpinska M, Rurek M (2018) Plant Glycine-Rich Proteins in Stress Response: An Emerging, Still Prospective Story. Front Plant Sci. 9:302.

Demiral T, Turkan I (2006) Exogenous glycine betaine affects growth and proline accumulation and retards senescence in two rice cultivars under $\mathrm{NaCl}$ stress. Environ Exp Bot. 56:7279.

Dubos C, Huggins D, Grant GH, Knight MR, Campbell MM (2003) A role for glycine in the gating of plant NMDA-like receptors. Plant J. 5:800-810.

Forde BG, Roberts MR (2014) Glutamate receptor-like channels in plants: a role as amino acid sensors in plant defense? F1000Prime Rep. 37: 6-37.

Heath RL, Packer L (1968) Photoperoxidation in isolated chloroplasts. I. Kinetics and stoichiometry of fatty acid peroxidation. Arc Biochem Biophys. 125: 189-198.

Hogan ME, Swift IE, Done HJ (1983) Urease assay and ammonia release from tissue. Phytochemistry. 22: 663-667.
Hu L., Hu T., Zhang X, Pang H, Fu J (2012) Exogenous Glycine Betaine Ameliorates the Adverse Effect of Salt Stress on Perennial Ryegrass. J Am Soc Hortic Sci. 137:38-44.

Igamberdiev AU, Kleczkowski LA (2018) The glycerate and phosphorylated pathways of serine synthesis in plants: The branches of plant glycolysis linking carbon and nitrogen metabolism. Front Plant Sci. 9:318.

Johnson CM, Stout PR, Broyer TC, Carlton AB (1957) Comparative chlorine requirement of different plant species. Plant Soil. 8: 337-353.

Kar M, Mishra D (1976) Catalase, peroxidase, and polyphenol oxidase activities during rice leaf senescence. Plant Physiol. 57: 315-319.

Khan S, Yu H, Li Q, Gao Y, Sallam BN, Wang H, Liu P, Jiang W (2019) Exogenous application of amino acids improves the growth and yield of lettuce by enhancing photosynthetic assimilation and nutrient availability. Agronomy. 9(5):266.

Lin $\mathrm{YC}$, Araguirang GE, Ngo AH, Lin K-T, Angkawijaya AE, Nakamura Y (2020). The four Arabidopsis choline/ethanolamine kinase isozymes play distinct roles in metabolism and development. Plant Physiol. 183: 152-166.

Matysiak K, Kierzek R, Siatkowski I, Kowalska J, Krawczyk R, Miziniak W (2020) Effect of exogenous application of amino acids I-arginine and glycine on maize under temperature stress. Agronomy. 10(6):769.

McCullough $\mathrm{H}$ (1967) The determination of ammonia in whole blood by direct colorimetric method. Clin Chim Acta. 17: 297-298.

Mohammadipour N, Souri MS (2019) Beneficial effects of glycine on growth and leaf nutrient concentrations of coriander (Coriandrum sativum) plants, J Plant Nutr. 42:14, 1637-1644.

Mosa WFA, Ali HM, Abdelsalam NR (2021) The utilization of tryptophan and glycine amino acids as safe alternatives to chemical fertilizers in apple orchards. Environ Sci Pollut Res. 28: 1983-1991.

Mulder EG, Boxma R, Veen WLV (1959) The effect of molybdenum and nitrogen deficiencies on nitrate reduction in plant tissues. Plant Soil. 10:335-355.

Noroozlo YA, Souri MK, Delshad M (2019a) Effects of foliar application of glycine and glutamine amino acids on growth and quality of sweet basil. Adv Hort Sci. 33(4): 495501

Noroozlo YA, Souri MK, Delshad M (2019b) Stimulation effects of foliar applied glycine and glutamine amino acids on lettuce growth. Open Agric. 4: 164-172.

Peixoto HPP, Cambraia J, Sant'ana R, Mosquim PR, Moreira AM (1999) Aluminum effects on lipid peroxidation and the activities of enzymes of oxidative metabolism in sorghum. Braz J Plant Physiol. 11(3): 137-143.

Price MB, Jelesko J, Okumoto S (2012) Glutamate receptor homologs in plants: functions and evolutionary origins. Front Plant Sci. 3:235.

Qiu XM, Sun YY, Ye XY, Li, ZG (2020). Signaling role of glutamate in plants. Front Plant Sci. 24.

Ramos-Ruiz R, Martinez F, Knauf-Beiter G (2019). The effects of GABA in plants. Cogent Food Agric. 5: 1670553.

Reis L, Santos e Silva CM, Bezerra B, Mutti P, Spyrides MH, Silva $P$, Magalhães T, Ferreira R, Rodrigues $D$, Andrade L. (2020) Influence of climate variability on soybean yield in Matopiba, Brazil. Atmosphere. 11(10):1130.

Ringli C, Keller B, Ryser U (2001) Glycine-rich proteins as structural components of plant cell walls. Cell Mol Life Sci. 58:1430-1441. 
Salazar C, Hernandez C, Pino MT (2015) Plant water stress: Associations between ethylene and abscisic acid response. Chilean J Agric Res. 75: 71-79.

Sas Institute (2011) SAS/STAT Statistical Analysis System Manual (v.9.3). Cary, NC: SAS Institute.

Sentelhas PC, Battisti R, Câmara, GMS, Farias JRB, Hampf AC, Nendel C (2015) The soybean yield gap in Brazil magnitude, causes and possible solutions for sustainable production. J Agric Sci. 153(8), 1394-1411.

Shehzadi A, Akram NA, Ali A, Ashraf M (2019) Exogenously applied glycinebetaine induced alteration in some key physio-biochemical attributes and plant anatomical features in water stressed oat (Avena sativa L.) plants. J Arid Land. 11: 292-305.

Shooshtari FZ, Souri MK, Hasandokht MR, Jari SK (2020) Glycine mitigates fertilizer requirements of agricultural crops: case study with cucumber as a high fertilizer demanding crop. Chem Biol Technol Agric. 7: 19.

Taiz L, Zeiger E, Moller IM, Murphy A (2017) Fisiologia e desenvolvimento vegetal. 6.ed. Porto Alegre: Artmed, 888p.

Teisseire H, Guy V (2000) Copper-induced changes in antioxidant enzymes activities in fronds of duckweed (Lemna minor). Plant Sci. 153: 65-72.

Teixeira WF, Fagan EB, Soares LH, Cabral EMA, Dourado-Neto D (2018) Changes in Root Architecture After Amino Acid Application in a Soybean Crop. J Agric Sci. 11(1): 325-334.
Teixeira WF, Fagan EB, Soares LH, Umburanas RC, Reichardt K, Dourado-Neto D (2017) Foliar and Seed Application of Amino Acids Affects the Antioxidant Metabolism of the Soybean Crop. Front Plant Sci. 8: 1-14.

Teixeira WF, Soares LH, Fagan EB, Mello S. da C, Reichardt K, Dourado-Neto D (2019) Amino acids as stress reducers in soybean plant growth under different water-deficit conditions. J Plant Growth Regul. 1-15.

United States Department of Agriculture - USDA. Available in: $<$

https://ipad.fas.usda.gov/cropexplorer/pecad_stories.aspx ?regionid=br\&ftype=prodbriefs $>$. Access in: April 01, 2021.

Wang C, Linderholm HW, Song Y, Wang F, Liu Y, Tian J, Xu J, Song Y, Ren G (2020) Impacts of drought on maize and soybean production in northeast china during the past five decades. Int J Environ Res Public Health. 17(7):2459.

Weiland M, Mancuso S, Baluska F (2015) Signalling via glutamate and GLRs in Arabidopsis thaliana. Funct Plant Bio. 43:1-25.

Xu Z, Sun M, Jiang X, Sun H, Dang X, Cong H, Qiao F (2018) Glycine betaine biosynthesis in response to osmotic stress depends on jasmonate signaling in watermelon suspension cells. Front Plant Sci. 9: 1469. 